\title{
Edukacja włączająca uczniów niepełnosprawnych - aktualne wyzwania
}

\section{Inclusive education for students with disability - the contemporary challenges}

\begin{abstract}
Streszczenie:
Artykuł porusza problematykę edukacji włączającej uczniów niepełnosprawnych w kontekście wyzwań związanych z realizacją idei inkluzji. Omawiając kategorie specjalnych potrzeb edukacyjnych i rozwojowych uczniów niepełnosprawnych, autorka dokonuje analizy miejsca ucznia niepełnosprawnego w systemie edukacji oraz możliwych form realizacji kształcenia (od segregacji przez integrację do inkluzji). Podjęte w artykule analizy uwarunkowań edukacji inkluzyjnej wskazują na szeroki kontekst wyzwań związanych z jej wdrażaniem. Nowa perspektywa, skoncentrowana na optymalizacji procesu kształcenia wszystkich uczniów, wymaga wprowadzenia istotnych zmian w myśleniu o edukacji i jej celach, ale także modyfikacji treści, koncepcji, struktur i strategii działania. Kluczowym zadaniem edukacji włączającej jest przekształcenie systemu oświatowego w sferze programowej i organizacyjnej tak, aby odpowiedzieć na zróżnicowane potrzeby uczniów i zapewnić im realizację ich indywidualnego potencjału. Efektywne wdrażanie założeń edukacji inkluzyjnej opierać się powinno na kompleksowym przygotowaniu nauczycieli, rozwijaniu ich kwalifikacji i kompetencji odpowiedzialnego działania w jej obszarze. Nauczyciele nie są jednak jedynymi ogniwami w procesie rozwoju szkoły włączającej, lecz stanowią jedynie część szerszego systemu, którego najważniejsze komponenty stanowiące wyzwanie dla realizacji idei stały się przedmiotem podjętych analiz.
\end{abstract}

Słowa kluczowe: edukacja włączająca/inkluzyjna, uczeń z niepełnosprawnością, specjalne potrzeby edukacyjne, szkoła dla wszystkich 
Agnieszka Szpak - Edukacja włączająca uczniów...

\begin{abstract}
:
The article discusses the issue of inclusive education of students with disabilities in the context of challenges associated with the implementation of the idea of inclusion. Discussing the categories of special educational needs and development of students with disabilities, the author analyses the place of a student with a disability in the education system, and the possible implementation model of education (from segregation, through integration, till inclusion). Analyses of inclusive education conditions indicate the broad context of the challenges associated with their implementation. The new perspective, focused on the optimizing the educational process of all students, requires significant changes in thinking about education and its objectives, but also modifying the content, concepts, structures and strategies. The key task of inclusive education is to transform the educational system in its program and organization in order to respond to the various needs of students and provide them opportunity of realizing their individual potential. Effective implementation of inclusive education should be based on the teachers comprehensive preparation, developing their skills and competences of responsible action in the area. Teachers are not the only elements in the process of inclusive school development, but they are part of a wider system discussed in the article.
\end{abstract}

Keywords: inclusive education, handicapped education, special educational needs, education for all

Włączanie jest procesem, pewna podróżą raczej niż punktem przeznaczenia

[P. Mittler]

\title{
Wprowadzenie
}

Uczenie się jest jednym z najbardziej skomplikowanych rodzajów ludzkiej działalności, a jego końcowe efekty zależą od wielu rożnych czynników. Wśród nich czołową pozycję zajmują dyspozycje psychiczne oraz funkcjonowanie procesów poznawczych (spostrzeganie, uwaga, zainteresowania, motywacja osiągnięć, aspiracje, pamięć, myślenie (analiza, synteza, abstrahowanie, uogólnianie - wnioskowanie, dowodzenie, tłumaczenie, sprawdzanie, rozumowanie indukcyjne i dedukcyjne), pojęcia, sądy oraz myślenie twórcze ${ }^{1}$. Skuteczność procesu kształcenia warunkują jednak nie tylko cechy ucznia, ale także szeroki kontekst środowiskowy, wyznaczany przez właściwości nauczyciela

\footnotetext{
1 Por. Cz. Kupisiewicz, Dydaktyka ogólna, Warszawa 2000, s. 203-211.
} 
oraz czynniki determinujące sytuację uczenia się i nauczania. Efekt procesu kształcenia określany jest jako rezultat celowej działalności szkoły i zorganizowanego procesu uczenia się, a osiągnięcia szkolne odnoszą się zarówno do nabytej zdolności poznawczej i sprawnościowych cech dziecka, warunkujących poprawne wykonanie określonych czynności - osiągnięć szkolnych poznawczych, jak również osiągnięć motywacyjnych, dotyczących kierunkowych cech osobowości, tj. zainteresowań, nawyków, postaw, zaangażowania, ambicji, motywacji czy chęci uczenia się².

Analiza determinantów procesu kształcenia pozwala na poszukiwanie nowych metod zwiększających efektywność nauczania i uczenia się. Potrzeba poszukiwania nowatorskich rozwiązań wynika $\mathrm{z}$ dynamicznych przemian cywilizacyjnych oraz nowych zadań stawianych edukacji we współczesnym świecie. Koncentrując się jednak na zwiększaniu skuteczności działań pedagogicznych oraz rozwijaniu kompetencji kluczowych jako warunku sukcesu edukacyjnego oraz osobistego, nie można zapominać o grupie uczniów borykających się z trudnościami i niepowodzeniami na obu tych płaszczyznach.

\section{Niepowodzenia - trudności - potrzeby edukacyjne}

Niepowodzenia szkolne określane są jako sytuacje charakteryzujące się występowaniem wyraźnych rozbieżności pomiędzy wymaganiami wychowawczymi i dydaktycznymi szkoły a postępowaniem uczniów oraz uzyskiwanymi przez nich wynikami nauczania ${ }^{3}$. W kontekście rozwojowym niepowodzenia szkolne oznaczają proces pojawiania się i utrwalania rozbieżności między celami edukacji a osiągnięciami szkolnymi uczniów i kształtowaniem się negatywnego stosunku jednostek wobec szkoły 4 .

\footnotetext{
2 Por. B. Niemierko, Diagnostyka dydaktyczno-wychowawcza, [w:] W. Pomykało (red.), Encyklopedia pedagogiczna, Warszawa 1993.

3 Cz. Kupisiewicz, Dydaktyka ogólna..., op. cit., s. 212.

${ }^{4}$ W. Okoń, Nowy słownik pedagogiczny, Warszawa 1995, s. 190.
} 
Agnieszka Szpak - Edukacja włączająca uczniów...

Determinanty niepowodzeń szkolnych są najczęściej opisywane w literaturze przedmiotu w odniesieniu do trzech kategorii przyczyn:

- biopsychicznych, związanych ze stanem zdrowia ucznia, ogólnym poziomem jego rozwoju psychofizycznego, cech charakteru i temperamentu;

- dydaktycznych - względnie zależnych od nauczyciela obejmujących niedostateczne przygotowanie zawodowe, błędy dydaktyczne, wadliwą postawę nauczyciela w stosunku do ucznia oraz względnie niezależnych od nauczyciela: przeładowanie programów nauczania, stan wyposażenia sal w sprzęt i pomoce naukowe, podręczniki szkolne, wady systemu klasowo-lekcyjnego;

- społeczno-ekonomicznych, na które składają się warunki materialne i mieszkaniowe uczniów, rozpad struktury rodziny, brak kontaktu z dzieckiem, brak zainteresowania jego pracą szkolną.

Niepowodzenia szkolne uważane są za najbardziej jednoznaczny wskaźnik trudności w uczeniu się - pojęcie to może odnosić się do zróżnicowanej grupy zaburzeń:

manifestujących się poprzez znaczące trudności w uczeniu się (w opanowaniu i stosowaniu umiejętności słuchowych, mówienia, czytania, pisania, rozumienia oraz umiejętności matematycznych) uwarunkowanych dysfunkcjami centralnego systemu nerwowego mogących współwystępować z innymi rodzajami niepełnosprawności (np. defektami sensorycznymi, upośledzeniem umysłowym, zaburzeniami rozwoju emocjonalnego i społecznego), jak również z konsekwencjami wpływów środowiska (np. różnić kulturowych, nieodpowiedniego czy niewłaściwego wychowania, czynników psychogennych), nie są one jednak bezpośrednim następstwem działania tych warunków i wpływów 5 .

Trudności w uczeniu się mogą przyjmować formę niespecyficzną, obejmującą trudności w uczeniu się, odnoszące się do uczniów z zaburzeniami i odchyleniami rozwojowymi o zróżnicowanej etiologii, któ-

\footnotetext{
${ }^{5}$ Raport NJCLD ${ }^{5}$ [za:] D. P. Hallahan, J. M. Kauffman, Exceptional children: Introduction to special education (4th ed.). Englewood Cliffs, New Jersey 1988, s. 125.
} 
rzy wymagają specjalnej organizacji procesu edukacyjnego ${ }^{6}$ oraz specyficzną, odnoszącą się do uczniów:

(...) w normie intelektualnej, o właściwej sprawności motorycznej i prawidłowo funkcjonujących systemach sensorycznych, którzy mają trudności w przyswajaniu treści dydaktycznych, wynikające ze specyfiki ich funkcjonowania poznawczo-percepcyjnego ${ }^{7}$.

Uczniowie doświadczający niepowodzeń, nie będący w stanie podołać wymaganiom powszechnie obowiązującego programu edukacyjnego z uwagi na występowanie znacznie większych trudności w uczeniu się niż u rówieśników, włączeni zostali do kategorii osób o specjalnych potrzebach edukacyjnych (special education needs).

Termin „specjalne potrzeby edukacyjne” pojawił się po raz pierwszy w Raporcie Mary Warnock (1978)8, dokumencie postulującym odstąpienie od medycznej kategoryzacji uczniów oraz diagnozowanych u nich deficytów na rzecz podejścia pozytywnego bazującego na bardziej funkcjonalnym języku społecznego rozumienia ich potrzeb. W świetle treści raportu można wskazać, iż specjalne potrzeby edukacyjne dzieci i młodzieży wynikają ze zindywidualizowanego sposobu nabywania wiedzy i umiejętności w procesie uczenia się, określonego specyfiką ich funkcjonowania poznawczo-percepcyjnego. Specjalne potrzeby edukacyjne odnoszą się zarówno do grupy dzieci i młodzieży mającej trudności w uczeniu się, jak i do uczniów. Ich rozpoznanie pozwala na właściwy dobór metod, środków i oddziaływań dydaktyczno-wychowawczych prowadzący do zaspokojenia potrzeb, a tym

\footnotetext{
${ }^{6}$ Do których zaliczyć należy uczniów niewidomych słabowidzących, niesłyszących, słabosłyszących, z chorobami przewlekłymi, zaburzeniami psychicznymi, z niepełnosprawnością ruchową, zaburzeniami spektrum autyzmu, z upośledzeniem umysłowym, uczniów niedostosowanych społecznie, a także uczniów zagrożonych niedostosowaniem społecznym, uzależnieniem lub z zaburzeniami zachowania.

${ }^{7}$ Edukacja skuteczna, przyjazna i nowoczesna. Jak organizować edukację uczniów ze specjalnymi potrzebami edukacyjnymi? Przewodnik, MEN, Warszawa, 2010, s. 90.

8 The Warnock Report "Special Educational Needs Report of the Committee of Enquiry into the Education of Handicapped Children and Young People", London 1978, s. 36. http://www.educationengland.org.uk/documents/warnock/warnock1978.html [dostęp: 6-06-2016].
} 
Agnieszka Szpak - Edukacja włączająca uczniów...

samym stworzenia optymalnych warunków rozwoju intelektualnego i osobowościowego'.

Minister Edukacji Narodowej zaproponował następującą definicję specjalnych potrzeb edukacyjnych i rozwojowych ${ }^{10}$ :

- dzieci i młodzież ze specjalnymi potrzebami rozwojowymi i edukacyjnymi to te, u których stwierdza się spektrum objawów utrudniających lub uniemożliwiających funkcjonowanie: ruchowe, sensoryczne, poznawcze, w zakresie komunikacji, emocjonalno-społeczne i/lub psychiczne, wpływających na jakość życia i pełnienie ról społecznych teraz i/lub w przyszłości.

- dzieci i młodzież ze specjalnymi potrzebami rozwojowymi i edukacyjnymi to te, u których stwierdza się zagrożenie niepełnosprawnością, wszelkie dysfunkcje, dysharmonie lub niesprawności mogące mieć negatywny wpływ na dalszy rozwój ${ }^{11}$.

Rozpoznawanie i zaspokajanie indywidualnych potrzeb rozwojowych i edukacyjnych oraz rozpoznawanie indywidualnych możliwości psychofizycznych ucznia powinno stanowić podstawę wszelkich działań edukacyjnych, jednak jest szczególnie istotne w przypadku występowania trudności wynikających przede wszystkim:

- z niepełnosprawności;

- z niedostosowania społecznego;

- z zagrożenia niedostosowaniem społecznym;

- ze szczególnych uzdolnień;

- ze specyficznych trudności w uczeniu się;

- z zaburzeń komunikacji językowej;

- $\quad$ z choroby przewlekłej;

${ }_{9}^{9} \mathrm{Za}$ : J. Głodkowska (red.), Dydaktyka specjalna w przygotowaniu do kształcenia uczniów ze specjalnymi potrzebami edukacyjnymi. Podręcznik akademicki, Warszawa 2010, s. 41.

10 Zespół przyjął jednocześnie kryterium podziału ze względu na wiek, precyzując, iż pojęcie specjalnych potrzeb rozwojowych dotyczy dzieci od urodzenia do 3. roku życia lub rozpoczęcia nauki w szkole, termin specjalne potrzeby edukacyjne używa się natomiast w kontekście dzieci i młodzieży od 3. roku życia lub od momentu rozpoczęcia nauki w szkole do jej ukończenia.

11 Zespół Ekspertów ds. Specjalnych Potrzeb Edukacyjnych, Propozycja systemu edukacji dzieci i młodzieży ze specjalnymi potrzebami, Warszawa 2009, s. 15. 
- z sytuacji kryzysowych lub traumatycznych;

- z niepowodzeń edukacyjnych;

- z zaniedbań środowiskowych związanych z sytuacją bytową ucznia i jego rodziny, sposobem spędzania czasu wolnego i kontaktami środowiskowymi;

- z trudności adaptacyjnych związanych z różnicami kulturowymi, ze zmianą środowiska edukacyjnego, w tym związanych z wcześniejszym kształceniem za granicą ${ }^{12}$,

to jest kategorii włączonych w zakres specjalnych potrzeb edukacyjnych na mocy przywołanego rozporządzenia (Rozporządzenie Ministra Edukacji Narodowej z dnia 30 kwietnia 2013 r. w sprawie zasad udzielania i organizacji pomocy psychologiczno-pedagogicznej $w$ publicznych przedszkolach, szkołach i placówkach (Dz. U. 2013, poz. 532).

Pod pojęciem ucznia ze specjalnymi potrzebami edukacyjnymi rozumiemy zatem zarówno uczniów niepełnosprawnych, jak i jednostki przejawiające trudności w realizacji standardów wymagań programowych wynikające ze specyfiki ich funkcjonowania poznawczo-percepcyjnego, zdrowotnego, ograniczeń środowiskowych czy trudności adaptacyjnych, a także uczniów przejawiających szczególne uzdolnienia.

Na uwagę zasługuje fakt, iż w nowych przepisach regulujących kwestie udzielania pomocy psychologiczno-pedagogicznej tj. Rozporządzeniu Ministra Edukacji Narodowej z dnia 28 sierpnia 2017 r. zmieniającym rozporzq̨dzenie $w$ sprawie zasad udzielania pomocy psychologiczno-pedagogicznej w publicznych przedszkolach, szkołach i placówkach (Dz. U. 2017, poz. 1643) nie pojawia się pojęcie „specjalne potrzeby edukacyjne", a potrzeba rozpoznawania i zaspokajania potrzeb rozwojowych i edukacyjnych uczniów poszerzona zostaje o wyodrębnioną kategorię uczniów z zaburzeniami zachowania lub emocji.

\footnotetext{
12 Rozporzqdzenie Ministra Edukacji Narodowej z dnia 30 kwietnia 2013 r. w sprawie zasad udzielania i organizacji pomocy psychologiczno-pedagogicznej $w$ publicznych przedszkolach, szkołach i placówkach (Dz. U. 2013, poz. 532).
} 
Agnieszka Szpak - Edukacja włączająca uczniów...

Wymieniony katalog specjalnych potrzeb edukacyjnych nie wyczerpuje wszystkich możliwych sytuacji, w których wychowankowie przedszkola mogą wymagać specjalistycznego wsparcia. Dotyczy to między innymi sytuacji, gdy trudności dziecka wymagają długotrwałej, wieloprofilowej diagnozy. W takich przypadkach pomoc dla dziecka powinna zostać zorganizowana na podstawie rozpoznania dokonanego przez nauczycieli i specjalistów, którzy na każdym etapie działań na rzecz dziecka mogą korzystać ze wsparcia udzielanego przez instytucje zewnętrzne, między innymi przez specjalistów z poradni psychologiczno-pedagogicznej.

\section{Uczeń niepełnosprawny i jego miejsce w systemie edukacji}

Uczniem niepełnosprawnym jest uczeń posiadający orzeczenie o potrzebie kształcenia specjalnego z uwagi na jeden z rodzajów niepełnosprawności określony w przepisach prawa. Aktualne rozporządzenie Ministra Edukacji Narodowej ${ }^{13}$ określa warunki organizowania kształcenia, wychowania i opieki dla dzieci i młodzieży niepełnosprawnej, do której zalicza: niesłyszących, słabosłyszących, niewidomych, słabowidzących, z niepełnosprawnością ruchową, w tym z afazją, z niepełnosprawnością intelektualną w stopniu lekkim, umiarkowanym lub znacznym, z autyzmem, w tym z zespołem Aspergera, i z niepełnosprawnościami sprzężonymi; niedostosowanych społecznie oraz zagrożonych niedostosowaniem społecznym - wymagających stosowania specjalnej organizacji nauki i metod pracy.

System kształcenia specjalnego w Polsce obejmuje aktualnie trzy główne nurty: segregacyjny, integracyjny oraz inkluzyjny. Warto za-

13 Rozporządzenie Ministra Edukacji Narodowej z dnia 24 lipca 2015 r. w sprawie warunków organizowania kształcenia, wychowania i opieki dla dzieci i młodzieży niepełnosprawnych, niedostosowanych społecznie i zagrożonych niedostosowaniem społecznym (Dz. U. 2015, poz. 1113) oraz Rozporzqdzenie Ministra Edukacji Narodowej z dnia 28 sierpnia 2017 r. zmieniające rozporządzenie w sprawie warunków organizowania kształcenia, wychowania i opieki dla dzieci i młodzieży niepełnosprawnych, niedostosowanych społecznie i zagrożonych niedostosowaniem społecznym (Dz. U. 2017, poz. 1652). 
znaczyć, iż wszystkie formy kształcenia tworzą jeden system, postulujący równość wszystkich uczniów wobec prawa oraz dający możliwość wyboru indywidualnej drogi kształcenia.

System segregacyjny zakłada selekcję ze względu na rodzaj niepełnosprawności i opiera się na realizacji obowiązku szkolnego w szkołach specjalnych zgodnie z zasadą homogeniczności. Początki segregacyjnej formy kształcenia sięgają w Europie XVIII wieku, kiedy to zaczęły powstawać różne placówki organizujące specjalistyczną opiekę nad dziećmi niepełnosprawnymi. Postępujący proces instytucjonalizacji, a także swoista fragmentacja ${ }^{14}$, skutkowały tworzeniem coraz bardziej specjalistycznych oddziałów dla dzieci z różnymi zaburzeniami w rozwoju, przyczyniając się tym samym do dominacji w XX w. form edukacji segregacyjnej w większości państw europejskich.

Idea kształcenia niesegregacyjnego dojrzewała stopniowo, a pierwszym krokiem na drodze do jej realizacji było uznanie prawa osób niepełnosprawnych do bycia traktowanymi z szacunkiem równym innym członkom społeczeństwa i do umożliwienia im, dzięki odpowiedniemu wsparciu i kształceniu, maksymalnie normalnego funkcjonowania w społeczeństwie - określonego mianem normalizacji ${ }^{15}$. Według standardów światowych i europejskich, sformułowanych w licznych dokumentach międzynarodowych dotyczących praw człowieka ${ }^{16}$, każdy człowiek ma prawo do pełnego uczestnictwa i równych szans w życiu społecznym, a edukacja jako podstawowe prawo wszystkich ludzi, niezależnie od rasy, płci, miejsca zamieszkania czy stopnia niepełnosprawności, zajmuje w nich kluczowe miejsce.

${ }^{14}$ Fragmentacja, czyli skoncentrowanie się placówek specjalnych na coraz bardziej specyficznych dysfunkcjach (tj. elementach poszczególnych typów niepełnosprawności), [za:] V. Lechta, Pedagogika inkluzyjna, [w:] B. Śliwerski (red.), Pedagogika, T. 4: Subdyscypliny i dziedziny wiedzy o edukacji, Gdańsk 2010, s. 324.

15 Por. Wolfensberger W. The Principles of Normalization in Human Services, Toronto 1972.

16 Powszechna Deklaracja Praw Człowieka (1948); Konwencja Praw Dziecka (1989); Światowa Deklaracja Edukacji dla Wszystkich (1990); Standardowe Zasady Wyrównywania Szans Osób Niepełnosprawnych (1993). 
Agnieszka Szpak - Edukacja włączająca uczniów...

Poszukiwania nowych (niesegregacyjnych) form edukacji osób niepełnosprawnych sięgają lat 80. XX wieku, kiedy to koncepcja integracji stała się przedmiotem światowej debaty. Zdaniem A. Hulka - prekursora idei integracji w Polsce - polega ona na:

(...) maksymalnym włączaniu dzieci i młodzieży z odchyleniami od normy do zwykłych szkół oraz placówek oświatowych, umożliwiając im w miarę możliwości, wzrastanie w gronie zdrowych rówieśników ${ }^{17}$.

Edukacja integracyjna, stanowiąc niewątpliwy postęp w stosunku do segregacyjnych form kształcenia, może przyjmować różne formy organizacyjne - ich zakres i zarazem ewolucje prezentuje trójstopniowa klasyfikacja ${ }^{18}$ wyróżniająca:

- integrację lokalizacyjną, uwzględniającą klasy specjalne dla uczniów niepełnosprawnych organizowane w przestrzeni szkół ogólnodostępnych, nie zakładającą kontaktów pomiędzy grupami uczniów pełno- i niepełnosprawnych;

- integrację społeczną, zakładającą przewagę segregacyjnych form spędzania czasu w placówce edukacyjnej oraz doraźne kontakty pomiędzy obiema grupami;

- integrację funkcjonalną, opartą na rzeczywistej integracji uczniów niepełnosprawnych z pełnosprawnymi rówieśnikami w klasie szkolnej, realizowaną w formie klas integracyjnych.

Edukacja integracyjna, postulując równość szans edukacyjnych, stwarza szansę na uczestnictwo dziecka niepełnosprawnego w życiu szkoły; nadal jednak w tym podejściu dominuje medyczny model niepełnosprawności ${ }^{19}$ skupiony na deficytach ucznia.

17 A. Hulek, Integracyjny system nauczania i wychowania, [w:] A. Hulek (red.), Pedagogika rewalidacyjna, Warszawa 1977, s. 492.

18 P. Farrel, M. Ainscow, Making special education inclusive, London 2002, s. 153.

19 Indywidualny model niepełnosprawności uznaje zaburzenie, uszkodzenie lub dysfunkcję za cechę jednostki. Wyrasta on na gruncie tradycyjnej koncepcji niepełnosprawności, która podkreśla znaczenie uwarunkowań biologicznych, które stają źródłem negatywnej oceny odmienności jednostki przez społeczeństwo, G. Szumski, Pięć minut dla pedagogiki specjalnej. „Meritum 2”, 9.11.2009. 
Kształcenie uczniów niepełnosprawnych w szkołach ogólnodostępnych należało do jednego z głównych kierunków polityki oświatowej państwa w roku szkolnym 2012/2013. Od roku szkolnego 2014/ 2015 realizowany jest natomiast kierunek polityki oświatowej państwa pod nazwą „Edukacja włączająca uczniów niepełnosprawnych”. Włączanie uczniów niepełnosprawnych do kształcenia we wszystkich typach przedszkoli, szkół i placówek, w tym w szkołach ogólnodostępnych i integracyjnych, umożliwia elastyczny system kształcenia. Polska jest krajem, w którym aktualnie obecny jest model wielu ścieżek edukacyjnych, charakteryzujący się możliwością wyboru formy kształcenia w ramach systemu oświaty. Kształcenie, wychowanie i opieka dla uczniów niepełnosprawnych, w myśl Rozporzq̨dzenia Ministra Edukacji Narodowej z dnia 9 sierpnia 2017 r. w sprawie warunków organizowania kształcenia, wychowania i opieki dla dzieci i młodzieży niepełnosprawnych, niedostosowanych społecznie i zagrożonych niedostosowaniem społecznym (Dz. U. 2017, poz. 1578) może odbywać się bowiem w:

- przedszkolach (ogólnodostępnych, ogólnodostępnych z oddziałami integracyjnymi, integracyjnych, ogólnodostępnych z oddziałami specjalnymi, specjalnych),

- oddziałach przedszkolnych w szkołach podstawowych,

- innych formach wychowania przedszkolnego,

- szkołach (ogólnodostępnych, ogólnodostępnych z oddziałami integracyjnymi, integracyjnych, ogólnodostępnych z oddziałami specjalnymi, specjalnych),

- młodzieżowych ośrodkach wychowawczych,

- młodzieżowych ośrodkach socjoterapii,

- specjalnych ośrodkach szkolno-wychowawczych,

- specjalnych ośrodkach wychowawczych,

- ośrodkach rewalidacyjno-wychowawczych.

Diagnozy potrzeb rozwojowych i edukacyjnych oraz możliwości psychofizycznych ucznia niepełnosprawnego dokonują specjaliści w poradni psychologiczno-pedagogicznej, którzy wskazując w orze- 
Agnieszka Szpak - Edukacja włączająca uczniów...

czeniu o potrzebie kształcenia specjalnego, zalecają formy kształcenia, wspierają rodziców w wyborze szkoły najbardziej odpowiedniej dla dziecka. Natomiast decyzję o wyborze formy i miejsca kształcenia podejmują rodzice (opiekunowie prawni) dziecka, którzy zgodnie z Konstytucją Rzeczpospolitej Polskiej mają wyłączne prawo do decydowania o swoim dziecku.

Rozporządzenie ${ }^{20}$ dotyczące warunków organizowania kształcenia, wychowania i opieki dla dzieci niepełnosprawnych i młodzieży, zapewniające możliwość kształcenia uczniów niepełnosprawnych w placówkach ogólnodostępnych, integracyjnych oraz specjalnych, zalicza jednocześnie uczniów niepełnosprawnych do wymagających stosowania specjalnej organizacji nauki i metod pracy. Uczniowie posiadający orzeczenie o potrzebie kształcenia specjalnego stają się więc jednostkami, które potrzebują: specjalnych warunków do nauki, specjalistycznego sprzętu i środków dydaktycznych zapewniających realizację zaleceń zawartych w orzeczeniu o potrzebie kształcenia specjalnego; indywidualnych programów edukacyjno-terapeutycznych, specjalistycznych zajęć oraz innych zajęć odpowiednich ze względu na indywidualne potrzeby rozwojowe i edukacyjne oraz możliwości psychofizyczne uczniów; zespołu specjalistów organizujących/współorganizujących kształcenie specjalne, jak również integracji ze środowiskiem rówieśniczym, w tym z uczniami pełnosprawnymi.

Nowy nurt myślenia o edukacji wychodzącej naprzeciw potrzebom uczniów niepełnosprawnych oparty jest na społecznym modelu niepełnosprawności, zakładającym, iż niepełnosprawność nie jest problemem jednostkowym, indywidualnym, lecz społecznym. Konsekwencją takiego podejścia jest zmiana sposobu myślenia o edukacji osób z niepełnosprawnością oraz postulowanie konieczności stworzenia nowego systemu pedagogicznego wymagającego radykalnych zmian odnoszących się do koncepcji edukacji, jej organizacji, miejsca

20 Rozporządzenie Ministra Edukacji Narodowej z dnia 9 sierpnia 2017 r. w sprawie warunków organizowania kształcenia, wychowania i opieki dla dzieci i młodzieży niepełnosprawnych, niedostosowanych społecznie i zagrożonych niedostosowaniem społecznym (Dz. U. 2017, poz. 1578). 
i roli poszczególnych uczestników tego procesu, jak również możliwości oceny skuteczności modyfikacji strukturalnych, organizacyjnych i programowych ${ }^{21}$. W tym kontekście podstawowa idea integracji sukcesywnie przechodzi w nową, zupełnie odmienną jakościowo formę edukację inkluzyjną. Niektórzy teoretycy podkreślają, że idea edukacji inkluzyjnej wyrosła z krytyki teorii i praktyki kształcenia integracyjnego, jego mankamentów i ograniczeń i jest propozycją doskonalszej organizacji wspólnego nauczania zdrowych i niepełnosprawnych ${ }^{22}$; skupioną przede wszystkim na zmianie systemu, a nie jednostki. Jak wskazuje Zbigniew Kwieciński:

(...) inkluzja (włączanie) jest kategorią opozycyjną wobec wykluczania, marginalizacji, segregacji osób odmiennych, odbiegających od normy zdrowotnej, kulturowej, społecznej albo niespełniających normatywnych oczekiwań lub dostosowujących się do wzorów instytucji i społeczności dominujących (w tym szkoły) ${ }^{23}$.

Edukacja inkluzyjna może być zatem postrzegana jako pewien nowy paradygmat myślenia o niesegregacyjnym kształceniu i działań na rzecz jego upowszechnienia. Początków idei inkluzji doszukiwać się można w Deklaracji z Salamanki, postulującej fundamentalne prawo do nauki, jak również konieczność stworzenia szansy osiągania i utrzymania odpowiedniego poziomu kształcenia dla wszystkich dzieci:

(...) każde dziecko ma charakterystyczne indywidualne cechy, zainteresowania, zdolności i potrzeby w zakresie nauczania; systemy oświaty powinny być tworzone, a programy edukacyjne wdrażane $\mathrm{z}$ uwzględnieniem dużego zróżnicowania tych charakterystycznych cech i potrzeb; dzieci o specjalnych potrzebach edukacyjnych muszą mieć dostęp do zwykłych szkół, które powinny je przyjąć $w$ ramach nauczania, stawiającego $w$ centrum zainteresowania s. 5-8.

${ }^{21}$ J. Głodkowska, W poszukiwaniu modelu edukacji włączającej. „Meritum 2”, 2009,

${ }^{22}$ G. Szumski, Od kształcenia integracyjnego do reedukacji inkluzyjnej - przemiany idei i praktyki, [w:] C. Kosakowski, A. Krause (red.), Dyskursy pedagogiki specjalnej. T. 3. Rehabilitacja, opieka i edukacja specjalna w perspektywie zmiany. Olsztyn: 2004, s. 42.

${ }^{23}$ Z. Kwieciński, Edukacja wobec różnicy i inkluzji. Dwa typy dyskursów - w stronę pedagogiki pozytywnej, [w:] Różnice, edukacja, inkluzja, A. Komorowska, T. Szkudlarek (red.), Gdańsk 2015, s. 23. 
Agnieszka Szpak - Edukacja włączająca uczniów...

dziecko i zdolnego zaspokoić jego potrzeby; zwykle szkoły o tak szerokiej orientacji są najskuteczniejszym środkiem zwalczania dyskryminacji, tworzenia przyjaznych społeczności, budowania otwartego społeczeństwa oraz wprowadzania w życie edukacji dla wszystkich, zapewniają one odpowiednie wykształcenie większości dzieci oraz poprawiają skuteczność, a także efektywność kosztową całego systemu oświaty ${ }^{24}$.

Edukacja inkluzyjna powinna być zatem postrzegana jako pomoc w rozwoju każdego człowieka, niezależnie od jakichkolwiek przeszkód. Jak wskazuje V. Lechta: „o ile integrację wiąże się z pedagogiką specjalnych potrzeb (special needs education), o tyle inkluzja dotyczy już szkoły dla wszystkich dzieci (education for all)"25. W tym nowym systemie edukacyjnym: „nie dominuje już zasada homogeniczności, wręcz przeciwnie: aplikuje się tu zasadę heterogeniczności"26. Włączanie nie oznacza więc asymilacji, tzn. podciągania wszystkich dzieci do jednego wzorca, a podstawową jego zasadą jest elastyczność - tzn. uznanie, że dzieci mogą uczyć się w różnym tempie, a nauczyciele powinni umieć wspierać ich naukę w sposób dostosowany do ich zróżnicowanych potrzeb, uzdolnień i tempa rozwoju ${ }^{27}$.

\section{Edukacja włączająca - implikacje i aktualne wyzwania}

Edukacja inkluzyjna - włączająca, jest procesem, którego efektywność uzależniona jest od wielu aspektów, w tym czynników indywidualnych, tkwiących w samej jednostce i poziomu jej zaangażowania w proces kształcenia. Sytuacja szkolna ucznia w ujęciu relacyjnym jest wypadkową czynników indywidualnych, tj. właściwości determinujących możliwość sprostania przez ucznia wymaganiom szkoły i peł-

${ }^{24}$ Deklaracja z Salamanki oraz Wytyczne dla działań w zakresie specjalnych potrzeb edukacyjnych, przyjęte przez Światową Konferencję Dotyczącą Specjalnych Potrzeb Edukacyjnych: Dostęp i Jakość, Salamanka, Hiszpania, UNESCO 1994, s. VIII.

25 V. Lechta, Pedagogika inkluzyjna..., op. cit., s. 331.

26 Ibidem, s. 324.

${ }^{27}$ A. Firkowska-Mankiewicz, Edukacja włączająca zadaniem na dziś polskiej szkoły, http://www.ore.edu.pl/component/phocadownload/category/177-ksztacenie-uczniwniepenosprawnych-w-szkoach-oglnodostpnych?download=1917:edukacja-wczajca-za daniem-na-dzi-polskiej-szkoy [dostęp: 15-08-2016]. 
nienia przypisanej roli ucznia oraz warunków zewnętrznych, tj. osób, zjawisk i sytuacji związanych z uczęszczaniem do szkoły. Ze względu na specyfikę wymogów szkolnych uczniowie z niepełnosprawnością często spotykają się z negatywnymi opiniami o sobie i swoich możliwościach, co ujemnie wpływa na rozwój samooceny czy motywacji oraz uniemożliwia stymulowanie i rozwijanie posiadanych możliwości. Uczniowie często obniżają swoje oczekiwania względem osiągnięcia sukcesu w przyszłości oraz zmniejszają poziom wysiłku wkładanego w działanie. Utrata zaufania do swoich zdolności, niska samoocena oraz brak poczucia kontroli powodują lęk, strach i bierność w podejmowaniu kolejnych wyzwań, a także wzmacniają poczucie bezradności.

Główną tendencją oddziaływań edukacyjnych zorientowanych na pomoc jednostkom ze specjalnymi potrzebami edukacyjnymi było dotychczas znalezienie sposobów na przystosowanie ich funkcjonowania do wymogów środowiska, tak aby mogły sprostać wymaganiom szkoły i programu nauczania. W tym modelu szkoła próbuje przystosować ucznia do swoich wymagań, naprawia deficyty i braki rozwojowe, nie koncentrując się na działaniach zmierzających $\mathrm{w}$ kierunku rozumienia indywidualnych potrzeb rozwojowych dziecka. Zgodnie z teoriami poznawczymi rozwój jednostki to jednak nie tylko postępująca adaptacja do środowiska, ale też modyfikacja środowiska do potrzeb jednostki. Różnorodność możliwości psychofizycznych oraz potrzeb rozwojowych i edukacyjnych wymaga indywidualizacji procesu kształcenia - postulowanego w systemie oświaty od dawna ${ }^{28}$, choć

28 Obowiązek indywidualizacji procesu nauczania został wskazany w przepisach ustawy o systemie oświaty, których uszczegółowieniem są regulacje zawarte w rozporządzeniach Ministra Edukacji Narodowej. Indywidualizacja przejawia się w dostosowaniu do potrzeb i możliwości psychofizycznych uczniów strategii edukacyjnych i wychowawczych, wykorzystywanych w codziennej pracy z uczniem, na każdych zajęciach prowadzonych przez nauczycieli. (...) Nauczyciel powinien umożliwić uczniom wybór sposobu osiągania celów i metod zdobywania wiedzy i umiejętności poprzez dostosowanie tempa zajęć, metod i form pracy, tak by zarówno angażować każdego ucznia z osobna, jak i organizować pracę całej klasy. Indywidualizacja jest przede wszystkim sposobem pracy z każdym uczniem, w tym ze specjalnymi potrze- 
Agnieszka Szpak - Edukacja włączająca uczniów...

w różnym stopniu realizowanego w praktyce szkolnej. Wartość postrzegania specjalnych potrzeb edukacyjnych jako przejawu indywidualnych potrzeb i możliwości zgodnie z ideą inkluzji opiera się na zmianie perspektywy percepcji ucznia zarówno w oczach nauczyciela czy rodzica, jak również samego dziecka, zdejmuje bowiem z niego piętno „zaburzenia”, daje szansę na myślenie o sobie samym w kategoriach własnych możliwości ${ }^{29}$.

Istotą indywidualnej ścieżki kształcenia każdego ucznia jest ujmowanie uczenia się jako procesu, którego głównym celem jest rozwijanie zdolności nabywania nowych umiejętności. W kontekście kluczowych czynników służących podnoszeniu jakości edukacji włączającej $^{30}$ niezmiernie ważne jest zatem wypracowanie u uczniów spersonalizowanego podejścia do procesu uczenia się opartego na określeniu przez ucznia (przy odpowiednim wsparciu ze strony nauczyciela i rodziny) celów edukacyjnych oraz opracowaniu indywidualnego toku nauki. Konieczne jest więc wypracowanie Indywidualnego Planu Nauczania bądź podobnego instrumentu kształcenia, służącego określonej grupie uczniów, w stosunku do których pojawić się może konieczność podjęcia specjalistycznej interwencji dla zwiększenia efektywności procesu kształcenia. Celem planu powinno być zagwarantowanie uczniom maksymalnej dozy niezależności, zapewnienie ich zaangażowania w proces wyznaczania celów edukacyjnych, a także maksymalne rozszerzenie zakresu współpracy z rodzicami uczniów.

Specyficzny typ podejścia do procesu nauczania, który ukierunkowany jest na zaspokajanie różnorakich potrzeb wszystkich uczniów bez zbędnego ich kategoryzowania, pozostający w zgodzie z zasadami

bami edukacyjnymi, w każdym oddziale i na każdych zajęciach (Edukacja włączajaca..., s. 8-9.).

${ }^{29}$ B. Dyrda, Style uczenia się dzieci dyslektycznych a wymagania poznawcze szkoły, Gdańsk 2003, s. 139.

30 European Agency for Development In Special Needs Education, 2009, Key Principles for Promoting Quality in Inclusive Education - Recomendations for Policy Makers, Odense, Denmark: European Agency for Development In Special Needs Education https://www.european-agency.org/sites/default/files/key-principles-for-promotingquality-in-inclusive-education_key-principles-PL.pdf [dostęp: 30-06-2016]. 
edukacji włączającej, wymaga następujących strategii i rozwiązań dydaktycznych i edukacyjnych:

- nauczania opartego na współpracy z innymi i koncepcji zespołowego systemu działania angażującego wszystkich uczestników procesu edukacyjnego - uczniów, ich rodziców, rówieśników, personelu wspomagającego i członków zespołu skupiającego specjalistów z różnych dziedzin;

- uczenia się i rozwiązywania problemów opartego na współpracy i współdziałaniu, przy elastycznym i optymalnym podziale uczniów na odpowiednie grupy (wewnętrzne zróżnicowanie oraz zindywidualizowane podejście do potrzeb każdego z uczniów), a także na sprawnym zarządzaniu aktywnością uczniów podczas zajęć;

- skutecznych metod nauczania, opartych na doborze odpowiednich celów nauczania, uwzględnieniu alternatywnych ścieżek kształcenia, elastyczności technik nauczania oraz stosowaniu jasnego przekazu informacji zwrotnej, w tym systemu oceniania wspierającego proces uczenia się opartego na holistycznej perspektywie pomiaru postępów ucznia i jasnego określenia kolejnych jego etapów ${ }^{31}$.

Przeniesienie punktu ciężkości z pedagogiki specjalnych potrzeb, skoncentrowanej na trudnościach, dysfunkcjach i deficytach, na rzecz wspierania potencjału i zasobów zgodnych z nurtem pedagogiki pozytywnej pozwala skoncentrować się na jednostce - wspieraniu jej rozwoju, ujawnianiu potencjału, odkrywaniu zdolności i zainteresowań, efektywnym społecznym włączaniu. Jak wskazuje Iwona Chrzanowska:

(...) zmierzanie drogą pełnego włączania wydaje się jedynym właściwym kierunkiem myślenia o edukacji. Tylko w ten sposób zostanie zniesiony sztuczny podział na pedagogikę i pedagogikę specjalną, wygenerowany przez psychologizm pedagogiczny i zasadę selekcji. Jedynie myślenie kategoriami uczeń, bez jego przymiotnikowego dookreślania, może zbliżyć nas do akceptacji wy-

31 Ibidem, s. 14-19. 
Agnieszka Szpak - Edukacja włączająca uczniów...

nikającej nie tyle z obowiązującego prawa, co wewnętrznego przekonania. Inkluzja uznana zasadą, powszechna i pełna, daje nadzieję na jedność pedagogiki w realizacji jej podstawowych celów - kształcenia i wychowania. Jest również szansą na wzajemne czerpanie z doświadczeń, pełniejsze zrozumienie dziecka/ucznia/studenta, rozwój teorii i praktyki dla rozwoju dyscypliny 32 .

Ten sposób patrzenia na indywidualne potrzeby każdego ucznia, nie tylko ucznia niepełnosprawnego, toruje drogę do efektywnej działalności edukacyjnej opartej na potrzebach i możliwościach psychofizycznych każdego wychowanka. Nowa perspektywa, skoncentrowana na procesie optymalizacji procesu kształcenia wszystkich uczniów, wymaga wprowadzenia istotnych zmian w myśleniu o edukacji i jej celach, ale także modyfikacji treści, koncepcji, struktur i strategii działania. Kluczowym zadaniem edukacji włączającej jest bowiem przekształcenie systemu oświatowego w sferze programowej i organizacyjnej tak, aby odpowiedzieć na zróżnicowane potrzeby uczniów i zapewnić im realizację ich indywidualnego potencjału. Służyć ma temu stworzenie odpowiedniego środowiska dla procesu kształcenia (zarówno uczenia się, jak i nauczania), w którym uczniowie i nauczyciele dobrze będą czuli się z tą różnorodnością i traktowali ją raczej jako wyzwanie i wzbogacenie środowiska uczenia się, niż jako problem ${ }^{33}$. W 2017 r. Ministerstwo Edukacji Narodowej wprowadziło szereg zmian w prawie ${ }^{34}$, których głównym postulowanym celem jest

\footnotetext{
32 I. Chrzanowska, Nauczanie inkluzyjne $w$ doświadczeniach polskich - podstawy prawne i społeczne uwarunkowania, „Studia Edukacyjne” 2014, nr 30, s. 112.

33 UNESCO 2008. 'Inclusive Education: The Way of the Future' (Edukacja właczajaca drogą do przyszłości), International Conference on Education, 48th session, Final Report, Geneva: UNESCO.

${ }^{34}$ Na mocy Rozporzqdzenia Ministra Edukacji Narodowej z dnia 28 sierpnia 2017 r. zmieniającego rozporządzenie $w$ sprawie zasad udzielania $i$ organizacji pomocy psychologiczno-pedagogicznej $w$ publicznych przedszkolach, szkołach i placówkach (Dz. U. 2017, poz. 1643); Rozporządzenia Ministra Edukacji Narodowej z dnia 9 sierpnia 2017 r. w sprawie zasad organizacji i udzielania pomocy psychologiczno-pedagogicznej w publicznych przedszkolach, szkołach i placówkach (Dz. U. z 2017 r., poz. 1591); Rozporządzenia Ministra Edukacji Narodowej z dnia 28 sierpnia 2017 r. zmieniającego rozporządzenie $w$ sprawie warunków organizowania kształcenia, wychowania i opieki dla dzieci i młodzieży niepełnosprawnych, niedostosowanych społecznie i zagrożonych niedostosowaniem społecznym (Dz. U. z 2017 r., poz. 1652); Rozpo-
} 
włączenie uczniów z różnymi potrzebami edukacyjnymi do grup rówieśniczych i zapewnienie im wszechstronnego wsparcia w dążeniu do rzeczywistego włączenia i integracji. Doskonaleniu jakości działań edukacyjnych oraz wspierających skierowanych do uczniów o specjalnych potrzebach edukacyjnych służyć mają następujące rozwiązania:

- doprecyzowanie przepisów dotyczących organizowania i udzielania pomocy psychologiczno-pedagogicznej;

- umożliwienie zróżnicowanego, elastycznego i optymalnego podejścia do pomocy psychologiczno-pedagogicznej;

- nowe możliwości współpracy placówek z poradnią psychologiczno-pedagogiczną;

- wprowadzenie nowych form pomocy psychologiczno-pedagogicznej (m.in. zajęć rozwijających umiejętności uczenia się czy zajęć rozwijających kompetencje społeczno-moralne);

- poszerzenie zakresu obserwacji prowadzonej w przedszkolach, szkołach i placówkach przez nauczycieli, wychowawców i specjalistów o rozpoznanie czynników środowiskowych wpływających na funkcjonowanie dziecka i mogących przyczyniać się do występowania u nich pierwszych symptomów trudności oraz podkreślenie znaczenia współpracy i pracy zespołowej35;

rzqdzenia Ministra Edukacji Narodowej z dnia 9 sierpnia 2017 r. w sprawie warunków organizowania kształcenia, wychowania i opieki dla dzieci i młodzieży niepełnosprawnych, niedostosowanych społecznie $i$ zagrożonych niedostosowaniem społecznym (Dz. U. 2017 r., poz. 1578); Rozporządzenia Ministra Edukacji Narodowej z dnia 28 sierpnia 2017 r. zmieniającego rozporzqdzenie $w$ sprawie indywidualnego obowiq̨zkowego rocznego przygotowania przedszkolnego dzieci i indywidualnego nauczania dzieci i młodzieży (Dz. U. z 2017 r., poz. 1656); Rozporzq̨dzenie Ministra Edukacji Narodowej z dnia 9 sierpnia 2017 r. w sprawie indywidualnego obowiq̨zkowego rocznego przygotowania przedszkolnego dzieci i indywidualnego nauczania dzieci i młodzieży (Dz. U. z 2017 r., poz. 1616).

35 Planowanie i koordynowanie działań mających na celu udzielanie pomocy psychologiczno-pedagogicznej w przedszkolu, szkole i placówce jest zadaniem zespołu, w którego skład wchodzą nauczyciele i specjaliści pracujący z dzieckiem oraz wychowawcy grup wychowawczych, prowadzący zajęcia z wychowankiem w danym ośrod$\mathrm{ku}$ (dodatkowo osoby wnioskowane oraz rodzice/opiekunowie dziecka). Ten sam zespół jest odpowiedzialny za przeprowadzenie wielospecjalistycznej oceny poziomy funkcjonowania ucznia. 
Agnieszka Szpak - Edukacja włączająca uczniów...

- zwiększenie zakresu możliwości indywidualizacji kształcenia w szkole, w tym możliwości prowadzenia zindywidualizowanej ścieżki kształcenia.

Skuteczność procesu kształcenia warunkują nie tylko cechy ucznia, ale także szeroki kontekst środowiskowy, wyznaczany przez właściwości nauczyciela oraz czynniki determinujące sytuację uczenia się i nauczania. Warunkiem podejmowania kompleksowych i efektywnych działań w obszarze edukacji włączającej jest zatem wypracowanie stosownego warsztatu dydaktycznego wykorzystywanego przez nauczycieli oraz ich kompleksowe przygotowanie, umożliwiające podejmowanie efektywnych działań wychodzących naprzeciw indywidualnym potrzebom wszystkich uczniów.

Peter Mittler zauważa, że jedną z podstawowych przeszkód nauczania włączającego/inkluzyjnego są negatywne postawy nauczycieli ${ }^{36}$ wobec uczniów z niepełnosprawnością. Jak wynika z badań prowadzonych na gruncie polskim przez Krystynę Błeszyńską blisko 85\% nauczycieli, gdyby mogła decydować, nie przyjęłaby do swojej klasy ucznia z niepełnosprawnością ${ }^{37}$, natomiast 66\% nauczycieli nie podjęłoby się pracy w placówkach integracyjnych ${ }^{38}$. Nauczyciele, wyjaśniając powody swoich nieakceptujących postaw wobec procesu inkluzji, najczęściej wskazują na brak własnych kwalifikacji do pracy z osobą niepełnosprawną 39 .

36 P. Mittler, Working Towards Inclusive Education, London 2000, s. 60.

37 K. Błeszyńska, Determinanty przystosowania ucznia niepełnosprawnego do środowiska szkoły masowej, [w:] A. Hulek, B. Grochmal-Bach (red.), Uczeń niepełnosprawny w szkole masowej, Kraków 1992, [za:] I. Chrzanowska, Nauczanie inkluzyjne..., op. cit., s. 113.

38 D. Al-Khamisy, Gotowość nauczycieli edukacji przedszkolnej do pracy z dziećmi o specjalnych potrzebach edukacyjnych, [w:] G. Dryżałowska, H. Żuraw (red.), Integracja społeczna osób niepełnosprawnych, Warszawa 2004, [za:] I. Chrzanowska, Nauczanie inkluzyjne..., op. cit., s. 113.

39 U. Bartnikowska, M. Wójcik, Zaniedbania w aspekcie triady: szkoła - rodzice dziecko w kształceniu integracyjnym i masowym dzieci z wadq słuchu, [w:] Z. Gajdzica, D. Osik-Chudowolska (red.), Watki zaniedbane, zaniechane, nieobecne $w$ procesie edukacji i wsparcia społecznego osób niepełnosprawnych, Lublin 2004, s. 188. 
Optymalne przygotowanie nauczycieli do efektywnej realizacji założeń edukacji inkluzyjnej opierać się zatem powinno zarówno na zwiększeniu ich świadomości, stanowiącej punkt wyjścia do kształtowania sprzyjających jej postaw społecznych i systemu wartości, jak również rozwijaniu kwalifikacji, a co za tym idzie kompetencji odpowiedzialnego działania w jej obszarze:

(...) wszyscy nauczyciele powinni rozwijać swoje umiejętności tak, by móc wyjść naprzeciw zróżnicowanym potrzebom każdego ucznia. Na każdym etapie kształcenia - zarówno początkowym, jak i późniejszych - nauczyciele powinni nabywać umiejętności, wiedzę i zrozumienie, które pozwolą im skutecznie radzić sobie z szerokim wachlarzem potrzeb uczniów"40.

Biorąc pod uwagę nowe rozwiązania prawne w obszarze udzielania pomocy psychologiczno-pedagogicznej w publicznych przedszkolach, szkołach i placówkach ${ }^{41}$, dostrzegamy nie tylko zmiany w definiowaniu pomocy psychologiczno-pedagogicznej jako polegającej na:

(...) rozpoznawaniu i zaspokajaniu indywidualnych potrzeb rozwojowych i edukacyjnych ucznia oraz rozpoznawaniu indywidualnych możliwości psychofizycznych ucznia i czynników środowiskowych wpływających na jego funkcjonowanie w szkole i placówce, w celu wspierania potencjału rozwojowego ucznia i stwarzania warunków do jego aktywnego i pełnego uczestnictwa w życiu szkoły i placówki oraz w środowisku społecznym ${ }^{42}$,

ale również poszerzenie i dookreślenie zadań nauczycieli, wychowawców i specjalistów w zakresie:

- rozpoznawania indywidualnych potrzeb rozwojowych i edukacyjnych oraz możliwości psychofizycznych uczniów;

- określania mocnych stron, predyspozycji, zainteresowań i uzdolnień uczniów;

${ }^{40}$ Europejska Agencja Rozwoju Edukacji Uczniów ze Specjalnymi Potrzebami, Kluczowe zasady służące promocji jakości w edukacji włączającej - zalecenia dotyczące praktyki, [bmw] 2011, s. 20.

${ }^{41}$ Omówione we wskazanych wcześniej rozporządzeniach.

42 Rozporzadzenie Ministra Edukacji Narodowej z dnia 28 sierpnia 2017 r. zmieniające rozporzqdzenie $w$ sprawie zasad udzielania i organizacji pomocy psychologiczno-pedagogicznej w publicznych przedszkolach, szkołach i placówkach (Dz. U. 2017, poz. 1643). 
Agnieszka Szpak - Edukacja włączająca uczniów...

- rozpoznawania przyczyn niepowodzeń edukacyjnych lub trudności w funkcjonowaniu uczniów, w tym barier i ograniczeń utrudniających funkcjonowanie uczniów i ich uczestnictwo w życiu szkoły i placówki;

- podejmowania działań sprzyjających rozwojowi kompetencji oraz potencjału uczniów w celu podnoszenia efektywności uczenia się i poprawy ich funkcjonowania;

- współpracy z poradnią w procesie diagnostycznym i postdiagnostycznym, w szczególności w zakresie oceny funkcjonowania uczniów, barier i ograniczeń w środowisku utrudniających funkcjonowanie uczniów i ich uczestnictwo w życiu szkoły lub placówki oraz efektów działań podejmowanych w celu poprawy funkcjonowania ucznia oraz planowania dalszych działań 43 .

Nowe zadania zawodowe z zakresie rozpoznawania specjalnych potrzeb edukacyjnych oraz przekonanie o gotowości nauczycieli do realizacji zadań w obszarze kształcenia uczniów o specjalnych potrzebach edukacyjnych i rozwojowych wynikają z założenia, że w toku kształcenia przygotowującego do wykonywania zawodu nauczyciela, w myśl obowiązujących standardów ${ }^{44}$, nauczyciele posiadają m. in. umiejętności i kompetencje niezbędne do kompleksowej realizacji dydaktycznych, wychowawczych i opiekuńczych zadań szkoły, w tym do samodzielnego przygotowania i dostosowania programu nauczania do potrzeb i możliwości uczniów.

W zakresie szczegółowych efektów kształcenia w odniesieniu do uczniów o specjalnych potrzebach edukacyjnych wskazano, iż każdy absolwent:

- posiada wiedzę na temat projektowania i prowadzenia badań diagnostycznych w praktyce pedagogicznej, poszerzoną w odniesieniu do odpowiednich etapów edukacyjnych i uwzględniającą specjalne potrzeby edukacyjne uczniów z zaburzeniami w rozwoju;

43 Ibidem.

${ }^{44}$ Zgodnie z Rozporządzeniem Ministra Nauki i Szkolnictwa Wyższego z dnia 17 stycznia 2012 r. w sprawie standardów kształcenia przygotowującego do wykonywania zawodu nauczyciela (Dz. U. 2012, poz. 131). 
- posiada wiedzę na temat podmiotów działalności pedagogicznej i partnerów szkolnej edukacji oraz specyfiki funkcjonowania dzieci i młodzieży w kontekście prawidłowości i nieprawidłowości rozwojowych;

- posiada wiedzę na temat specyfiki funkcjonowania uczniów ze specjalnymi potrzebami edukacyjnymi, w tym uczniów szczególnie uzdolnionych;

- posiada umiejętności diagnostyczne pozwalające na rozpoznawanie sytuacji uczniów ze specjalnymi potrzebami edukacyjnymi, opracowywanie wyników obserwacji i formułowanie wniosków;

- potrafi pracować z uczniami, indywidualizować zadania i dostosowywać metody i treści do potrzeb i możliwości uczniów (w tym ze specjalnymi potrzebami edukacyjnymi);

- w zakresie kompetencji społecznych - ma świadomość konieczności prowadzenia zindywidualizowanych działań pedagogicznych w stosunku do uczniów o specjalnych potrzebach edukacyjnych.

Obecnie trwają prace nad nowymi standardami, skoncentrowanymi nad podniesieniem jakości kształcenia przyszłych nauczycieli i optymalnym przygotowaniem ich do prowadzania kompleksowej diagnozy, spersonalizowanego procesu kształcenia uczniów o specjalnych potrzebach edukacyjnych i rozwojowych, a także efektywnej współpracy $\mathrm{z}$ otoczeniem $\mathrm{w}$ procesie wspierania rozwoju uczniów. W listopadzie i grudniu 2017 r. w całej Polsce odbywają się spotkania konsultacyjne w celu skonfrontowania wypracowanych przez zespół ekspertów wstępnych wersji programów kształcenia nauczycieli w ramach projektu „Opracowanie modelowych programów kształcenia nauczycieli", współfinansowanego ze środków Unii Europejskiej, realizowanego w ramach Programu Operacyjnego Wiedza - Edukacja Rozwój, które w konsekwencji zaowocują pojawieniem się nowych rozwiązań prawnych w tym zakresie.

Europejska Agencja Rozwoju Edukacji Uczniów ze Specjalnymi Potrzebami opublikowała dokument pt. Kształcenie nauczycieli przygoto- 
Agnieszka Szpak - Edukacja włączająca uczniów...

wujące do edukacji włączającej. Profil nauczyciela edukacji włączajq$c e j^{45}$ mający służyć jako poradnik pomocny przy tworzeniu i wdrażaniu programów skierowanych do wszystkich nauczycieli i studentów kierunków nauczycielskich. Zdefiniowano w nim system podstawowych wartości i obszarów kompetencji, które odnieść można do każdego programu początkowego kształcenia nauczycieli w celu przygotowania ich do edukacji włączającej z uwzględnieniem wszystkich form różnorodności.

Podstawowe wartości i obszary kompetencji obejmują:

\section{- Docenianie różnorodności}

Różnice pomiędzy uczniami uznawane są za zaletę - jako wartość i czynnik sprzyjający edukacji, a wskazane obszary kompetencji w ramach tej podstawowej wartości obejmują: koncepcję edukacji włączającej oraz przekonania nauczycieli na temat naturalnych różnic pomiędzy uczniami.

- Wspieranie wszystkich uczniów

Nauczyciele spodziewają się, że każdy uczeń dokona znaczących postępów w nauce. Aby tego dokonać, należy wyposażyć nauczyciela $\mathrm{w}$ kompetencje pozwalające na efektywne wspomaganie każdego ucznia w opanowywaniu treści przedmiotowych, nabywaniu umiejętności społecznych i rozwoju emocjonalnym, a także stosowanie skutecznych metod nauczania w klasach, do których uczęszczają uczniowie o zróżnicowanych potrzebach edukacyjnych.

- Indywidualny rozwój zawodowy

Nauczanie musi być oparte na uczeniu się - nauczyciele biorą na siebie zobowiązanie do uczenia się przez całe życie. Obszary kompetencji w ramach tej podstawowej wartości obejmują: nauczyciele to praktycy wyciągający wnioski z dotychczasowych do-

45 Europejska Agencja Rozwoju Edukacji Uczniów ze Specjalnymi Potrzebami, Kształcenie nauczycieli przygotowujące do edukacji włączającej. Profil nauczyciela edukacji włączającej, [bmw] 2012. 
świadczeń; początkowy etap kształcenia jest punktem wyjścia do kształcenia ustawicznego i doskonalenia zawodowego.

\section{- Nastawienie na współpracę}

Wszyscy nauczyciele uznają zasadniczą rolę pracy zespołowej i współdziałania. Obszary kompetencji w ramach tej podstawowej wartości obejmują: współpracę z rodzicami i rodzinami; współpracę z szerokim gronem pracowników sektora oświaty ${ }^{46}$.

Wprowadzenie edukacji włączającej należy postrzegać jako zadanie zbiorowe, z rożnymi zainteresowanymi stronami, z których każda ma do odegrania swoje role i pełni określone funkcje. Myślenie o wartościowej edukacji dzieci powinno się zatem rozwijać w nawiązaniu do koncepcji partnerstwa edukacyjnego. Jak wskazuje Maria Mendel:

(...) o partnerstwo edukacyjne zabiegają reformatorzy edukacji, tak w Polsce, jak innych krajach kształtujących demokratyczny porządek społeczny. W partnerach powinno rozwijać się wzajemne zaufanie i poczucie wspólnego posiadania przez nich pewnego dobra. Partnerstwo intensyfikować powinno kolegialność, w rozumieniu koleżeńskich interakcji nastawionych na współpracę, a także być skoncentrowane na problemach szkolnych, dostarczać satysfakcji osobom w nie zaangażowanym oraz kreować strukturę, umożliwiającą tworzenie oddolnych pomysłów i inicjatyw. W najprostszym ujęciu jest to rodzaj równej relacji wzajemnego wpływu, jaki wywierają na siebie poszczególne środowiska życia (edukacji) dziecka" ${ }^{47}$.

W tym ujęciu partnerstwo edukacyjne jest więc także ideą organizującą współpracę szkoły z domem oraz nauczyciela z rodzicami uczniów, a głównym źródłem partnerstwa rodziny i szkoły jest obopólne dążenie tych środowisk do rozwoju i szeroko rozumianego powodzenia edukacyjnego i (tym samym) życiowego dziecka. Zakres efektywnej współpracy środowisk edukacyjnych warunkuje bowiem nie tylko optymalizację procesu kształcenia, skoncentrowanego na potrzebach i możliwościach ucznia, ale także przyczynia się do kształtowania po-

46 Ibidem, s.8-9.

47 M. Mendel, Nauczyciel z uczniem, rodzicami i lokalnq społecznościq. Koncepcje partnerstwa edukacyjnego, [w:] M. Klus-Stańska, M. Szczepska-Pustkowska (red.), Pedagogika wczesnoszkolna, Warszawa 2009, s. 186-187. 
Agnieszka Szpak - Edukacja włączająca uczniów...

zytywnych postaw wobec uczenia się, rozwijania niezależności, a także budowania pozytywnego obrazu siebie i własnych kompetencji.

Nastawienie rodziców do edukacji inkluzyjnej warunkowane jest szeregiem czynników. Istotnym elementem jest poziom ich świadomości, ale także osobiste, często negatywne doświadczenia zebrane w toku edukacji dzieci z niepełnosprawnością. Jak podkreśla Peter Farrell, istnieją przekonujące dowody na to, że rodzice uczniów zdiagnozowanych jako uczniowie ze specjalnymi potrzebami edukacyjnymi czują się bezsilni wobec całego procesu diagnozowania i podkreślają, że w jego trakcie czuli na sobie ciężar odpowiedzialności za problemy/trudności występujące u dziecka ${ }^{48}$. Innym problemem jest również motywacja rodziców do współpracy ze szkołą nie tylko na poziomie decyzyjności dotyczącym ich własnego dziecka, ale także procesów zachodzących w szkole i mających nierozerwalny wpływ na jakość pracy szkoły.

Niezmiernie istotna jest zatem świadomość wartości dodanej, jaka wypływa ze współpracy z rodzicami, efektywna komunikacja i zrozumienie wpływu relacji interpersonalnych i metod opartych na współpracy na realizację celów nauczania, a w konsekwencji skuteczne angażowanie rodziców i rodzin we wspomaganie procesu uczenia się ich dziecka. Aby skutecznie włączać rodziców i współrealizować ideę edukacji inkluzyjnej, rodzice uczniów z niepełnosprawnością muszą uzyskać odpowiednie wsparcie informacyjne, emocjonalne i instrumentalne.

Wprowadzenie edukacji włączającej należy postrzegać jako zadanie zbiorowe, z różnymi zainteresowanymi stronami, z których każda ma do odegrania swoje role i pełni określone funkcje. Nauczyciele edukacji włączającej nie są jednak jedynymi ogniwami w procesie rozwoju szkoły włączającej, lecz stanowią jedynie część szerszego systemu. Wśród kluczowych zasad dotyczących promocji jakości edukacji

48 P. Farrell, Special education in the last twenty years: have things really Got better?, „British Journal of Special Education” 2001, nr 28(1), s. 5. 
włączającej ${ }^{49}$ oprócz rozszerzenia uczestnictwa w edukacji w celu zwiększenia możliwości nabywania wiedzy przez wszystkich uczniów oraz podkreślenia wagi szkolenia w zakresie edukacji włączającej obejmującej wszystkich nauczycieli, omówionych wcześniej w niniejszym artykule, wskazano na istotną rolę następujących elementów:

- Kultury organizacyjnej i etosu promującego edukację włączającą,

zakorzenionych w pozytywnym nastawieniu wobec idei otwarcia szkolnych klas na różnorodność społeczności uczniowskiej oraz zaspokajania zróżnicowanych potrzeb edukacyjnych. Kultura organizacyjna obejmująca wszystkich interesariuszy związanych z systemem kształcenia: uczniów, rodziców, nauczycieli i społeczności lokalne, tworzona jest przez osoby kierujące instytucjami stawiającymi sobie za cel realizację idei edukacji włączającej.

- Struktur wsparcia,

na które składa się cały szereg instytucji świadczących usługi specjalistyczne z różnych dziedzin oraz szereg postaw i metod działania, pozwalających na elastyczne reagowanie na szeroki zakres potrzeb organizacyjnych, specjalistycznych czy też rodzinnych. Interdyscyplinarne podejście do rozwiązywania problemów oraz skoordynowane działania (w obrębie różnych sektorów i w ramach poszczególnych zespołów) służyć mają wspieraniu ucznia w najlepszy możliwy sposób. Celem tych zintegrowanych działań jest skuteczne przechodzenie wszystkich uczniów na kolejne etapy ich całościowo zarysowanej ścieżki edukacyjnej.

- Elastycznego systemu finansowania:

finansowanie systemowych rozwiązań i struktur umożliwiających rozwój edukacji włączającej pozostaje jednym z najistotniejszych czynników mających wpływ na powodzenie całego pro-

\footnotetext{
${ }^{49}$ Sformułowanych przez Europejską Agencję Rozwoju Edukacji Uczniów ze Specjalnymi Potrzebami w dokumencie; zob. Europejska Agencja Rozwoju Edukacji Uczniów ze Specjalnymi Potrzebami, Kluczowe zasady służące promocji jakości w edukacji włączającej - zalecenia dotyczące praktyki, [bmw] 2011, s.16-26.
} 
Agnieszka Szpak - Edukacja włączająca uczniów...

jektu. Ograniczony dostęp do określonych świadczeń i technicznych udogodnień lub całkowity jego brak może poważnie zaszkodzić procesowi włączania uczniów z niepełnosprawnością w powszechny system kształcenia oraz poważnie naruszyć zasadę równych szans dla wszystkich.

- Programowych wytycznych:

idea szkoły dla wszystkich powinna być propagowana w ramach odpowiedniej polityki edukacyjnej (uwzględniającej międzynarodowe inicjatywy i wytyczne programowe, przy zachowaniu odpowiedniej elastyczności i otwartości na potrzeby społeczności lokalnych), konieczne jest wypracowanie właściwego etosu szkoły, odpowiedniego modelu zarządzania szkołą oraz stosownego warsztatu dydaktycznego wykorzystywanego przez nauczycieli. Istotą jest nie tylko prawidłowe odczytanie i wprowadzenie w życie przez osoby odpowiedzialne za kształt systemu edukacji wytycznych programowych, ale przede wszystkim komunikowanie idei edukacji włączającej wszystkim członkom społeczności szkolnej. Programowe wytyczne promujące edukację włączającą oraz zaspokajanie potrzeb poszczególnych uczniów we wszystkich sektorach systemu edukacji zakładają wysoki poziom koordynacji działań, przewidywania poszczególnych etapów realizacji wyznaczonego celu, a także uwzględniają sposób monitorowania procesu wprowadzania polityki edukacyjnej.

- Ustawodawstwa:

wszystkie rozwiązania ustawowe, które - choćby potencjalnie mogą wpływać na edukację włączającą, powinny w sposób wyraźny zmierzać w kierunku włączenia wszystkich uczniów w powszechny system kształcenia. Wewnętrznie spójne ustawodawstwo obejmujące wszystkie kwestie związane z ideą elastyczności, różnorodności i równości gwarantuje, że polityka oświatowa, oferta edukacyjna oraz formy wsparcia mają jednolity charakter.

Zmiany mające na celu wprowadzenie edukacji włączającej jako optymalnego systemu kształcenia dla wszystkich, nie tylko uczniów 
z niepełnosprawnością, mogą być dokonane przy uwzględnieniu przedstawionych wyżej ściśle ze sobą powiązanych zasad i zaangażowaniu wszystkich stron i sił. Tylko spójna koncepcja edukacji włączającej, oparta na rozwiązaniach ustawowych, systemowych, programowych, a także określonej strukturze organizacyjnej i odpowiednim systemie wsparcia, ma szansę na kreowanie przestrzeni dla tworzenia się szkoły dla wszystkich uczniów, w której nauczyciele będą mogli podejmować efektywne działania na rzecz kompleksowego wspierania ich nauki w sposób dostosowany do zróżnicowanych potrzeb, uzdolnień i tempa rozwoju każdej jednostki.

\section{Podsumowanie}

Jak wskazano na początku podjętych rozważań, włączanie jest procesem, a idea kształcenia inkluzyjnego to z pewnością przyszłość edukacji. Z badań nad efektywnością edukacji włączającej ${ }^{50}$ wynika, iż $\mathrm{w}$ efekcie procesu integracji i włączania odnotowujemy szereg korzystnych zmian: na poziomie indywidualnym dotyczą one zarówno samych osób niepełnosprawnych, jak i ich sprawnych rówieśników; na poziomie instytucjonalnym dotyczą przede wszystkim organizacji i funkcjonowania poszczególnych szkół i systemu edukacji; na poziomie ogólnospołecznym prowadzą do przemodelowania świadomości i postaw społecznych wobec osób z niepełnosprawnością. Wdrażanie idei inkluzji wymaga jednak zmian ideowych, koncepcyjnych, systemowych; wymaga odwagi i otwartości, przekonania o słuszności idei, ale także szerokiego wsparcia zarówno ze strony decydentów, jak i praktyków działających w obszarze edukacji.

Tocząca się debata nad szerszym włączeniem ma na celu zapewnienie wysokiej jakości kształcenia oraz przynieść korzyści wszystkim uczniom, jednak proces jej realizacji wiąże się z szeregiem wyzwań.

50 Por. G. Szumski, Wokół edukacji włączającej. Efekty kształcenia uczniów z niepełnosprawnościa intelektualna $w$ stopniu lekkim $w$ klasach specjalnych, integracyjnych i ogólnodostępnych, Warszawa, 2010. 
Agnieszka Szpak - Edukacja włączajq̨ca uczniów...

Konieczne jest kształtowanie sprzyjających jej postaw społecznych, nie tylko wśród grup zaangażowanych w proces kształcenia, a także dbałość o profesjonalne przygotowanie nauczycieli w zakresie wiedzy, umiejętności i kompetencji umożliwiających wspieranie uczniów i zaspokajanie różnorodnych potrzeb edukacyjnych. Istotą jest również wspieranie zaangażowania uczniów i ich rodziców przy podejmowaniu decyzji dotyczących procesu kształcenia - ich świadome uczestnictwo, poczucie sprawstwa, aktywna współpraca i współdziałanie na rzecz tworzenia szkoły na miarę XXI wieku. Budowanie środowiska edukacyjnego jako przestrzeni przyjaznej wszystkim uczestnikom tego swoistego projektu edukacyjnego i wdrażanie idei, jaką jest edukacja inkluzyjna. Wymaga ona rozwoju potencjału instytucji oświatowych, zapewnienia spójności pomiędzy prawem, polityką i praktyką oświatową, przejrzystości koncepcji oraz ciągłości wsparcia dla wszystkich zainteresowanych stron, skłaniając w ten sposób szkoły do porzucenia zachowawczych metod i podjęcia działań na rzecz szeroko pojętej inkluzji51. Jak wskazuje Iwona Chrzanowska:

(...) nie wolno pozwolić na inkluzję pozorną, idee dla idei. Wprowadzoną do systemu edukacji tylko dlatego, że jest trendy. Taka inkluzja nie będzie jednoczyła pedagogiki i pedagogiki specjalnej, odwrotnie - wskaże, że niemal wszystko je dzieli i kuriozalnie za jakiś czas może dowieść, że najlepszym rozwiązaniem w kształceniu osób niepełnosprawnych jest segregacja ${ }^{52}$.

\section{Bibliografia:}

Al-Khamisy D., Gotowość nauczycieli edukacji przedszkolnej do pracy z dziećmi o specjalnych potrzebach edukacyjnych, [w:] Integracja społeczna osób niepełnosprawnych, G. Dryżałowska, H. Żuraw (red.), Warszawa 2004.

Bartnikowska U., Wójcik M., Zaniedbania w aspekcie triady: szkoła - rodzice - dziecko w kształceniu integracyjnym i masowym dzieci z wadą słuchu,

${ }^{51}$ Europejska Agencja ds. Specjalnych Potrzeb i Edukacji Włączającej, Pięć kluczowych przesłań dla edukacji włączającej. Od teorii do praktyki, 2014, s. 16

https://www.europeanagency.org/sites/default/files/Five_Key_Messages_for_Inc lusive_Education_PL.pdf [dostęp: 12-08-2016].

52 I. Chrzanowska, Nauczanie inkluzyjne..., op. cit., s. 116. 
[w:] Watki zaniedbane, zaniechane, nieobecne w procesie edukacji i wsparcia społecznego osób niepełnosprawnych, Z. Gajdzica, D. Osik-Chudowolska (red.), Lublin 2004.

Chrzanowska I., Nauczanie inkluzyjne w doświadczeniach polskich - podstawy prawne i społeczne uwarunkowania, „Studia Edukacyjne” 2014, nr 30.

Deklaracja z Salamanki oraz wytyczne dla działań $w$ zakresie specjalnych potrzeb edukacyjnych, Dostęp i Jakość, Salamanka, Hiszpania, UNESCO 1994, s. VIII.

Dyrda B., Style uczenia się dzieci dyslektycznych a wymagania poznawcze szkoły, Wyd. UG, Gdańsk 2003.

Edukacja skuteczna, przyjazna i nowoczesna. Jak organizować edukację uczniów ze specjalnymi potrzebami edukacyjnymi? Przewodnik, MEN, Warszawa, 2010

Farrel P., Ainscow M., Making special education inclusive, London, David Fulton Publisher 2002.

Głodkowska J. (red.), Dydaktyka specjalna w przygotowaniu do kształcenia uczniów ze specjalnymi potrzebami edukacyjnymi. Podręcznik akademicki, Wyd. APS, Warszawa, 2010.

Głodkowska J., W poszukiwaniu modelu edukacji włączającej. „Meritum” 2009, nr 2.

Hallahan D.P., Kauffman J.M., Exceptional children: Introduction to special education (4th ed.). Englewood Cliffs, Prentice Hall, 1988.

Hulek A., Integracyjny system nauczania i wychowania, [w:] A. Hulek (red.): Pedagogika rewalidacyjna. Warszawa, 1977.

Kupisiewicz Cz., Dydaktyka ogólna, Wyd. WSiP, Warszawa, 2000.

Kwieciński Z., Edukacja wobec różnicy i inkluzji. Dwa typy dyskursów - w stronę pedagogiki pozytywnej, [w:] A. Komorowska, T. Szkudlarek (red.), Różnice, edukacja, inkluzja, Wyd. WUG, Gdańsk 2015.

Lechta V., Pedagogika inkluzyjna, [w:] B. Śliwerski (red.), Pedagogika, T. 4: Subdyscypliny i dziedziny wiedzy o edukacji, Wyd. GWP, Gdańsk 2010.

Mendel M., Nauczyciel z uczniem, rodzicami i lokalnq społecznością. Koncepcje partnerstwa edukacyjnego (w:) M. Klus-Stańska, M. Szczepska-Pustkowska (red.), Pedagogika wczesnoszkolna, Wyd. WAiP, Warszawa 2009.

Mittler P., Working Towards Inclusive Education, London 2000.

Niemierko B., Diagnostyka dydaktyczno-wychowawcza, [w:] W. Pomykało (red.), Encyklopedia pedagogiczna, Wyd. Fundacja Innowacja, Warszawa 1993. 
Agnieszka Szpak - Edukacja włączająca uczniów...

Okoń W., Nowy słownik pedagogiczny, Wyd. Żak, Warszawa 1995.

Piaget J., Mowa i myślenie u dziecka, Wyd. PWN, Warszawa 1992.

Rowley D., Jak budować szczęśliwą przyszłość osób ze znacznq niepełnosprawnościq intelektualnq̨? [w:] G. Fairbairn, S. Fairbairn (red.), Integracja dzieci o specjalnych potrzebach, Wyd. CMPPP MEN, Warszawa 2000.

Sternberg R.J., Thinking styles, Cambridge University Press, Cambridge 1997.

Szumski G, Wokół edukacji włączającej. Efekty kształcenia uczniów z niepełnosprawnościq intelektualnq $w$ stopniu lekkim $w$ klasach specjalnych, integracyjnych i ogólnodostępnych, Wyd. APS, Warszawa, 2010.

Szumski G., Pięć minut dla pedagogiki specjalnej. „Meritum” 2009, nr 2.

Szumski, G., Od kształcenia integracyjnego do reedukacji inkluzyjnej - przemiany idei i praktyki, [w:] C. Kosakowski, A. Krause (red.), Dyskursy pedagogiki specjalnej, T. 3: Rehabilitacja, opieka i edukacja specjalna $w$ perspektywie zmiany, Wyd. UWM, Olsztyn 2004.

UNESCO 2008, Inclusive Education: The Way of the Future, (Edukacja właczająca droga do przyszłości), International Conference on Education, 48th session, Final Report, Geneva: UNESCO.

Zespół Ekspertów ds. Specjalnych Potrzeb Edukacyjnych, Propozycja systemu edukacji dzieci i młodzieży ze specjalnymi potrzebami, Wyd. MEN, Warszawa 2009.

\section{Netografia:}

European Agency for Development In Special Needs Education, 2009, Key Principles for Promoting Quality in Inclusive Education - Recomendations for Policy Makers, Odense, Denmark: European Agency for Development In Special Needs Education https://www.european-agency.org/sites/ default/ files/key-principles-for-promoting-quality-in-inclusive-education_keyprinciples-PL.pdf [dostęp: 30-06-2017 r.]

Europejska Agencja ds. Specjalnych Potrzeb i Edukacji Włączającej, Pięć kluczowych przesłań dla edukacji włączającej. Od teorii do praktyki, 2014, https://www.european-agency.org/sites/default/files/Five_Key_Messa ges_for_Inclusive_Education_PL.pdf [dostęp: 30-06-2017 r.]

Europejska Agencja Rozwoju Edukacji Uczniów ze Specjalnymi Potrzebami, Kluczowe zasady służące promocji jakości w edukacji włączającej - zalecenia dotyczace praktyki, 2011, https://www.european-agency.org/sites/ default/files/key-principles-for-promoting-quality-in-inclusive-educa tion_key-principles-PL.pdf [dostęp: 10-09-2017] 
Europejska Agencja Rozwoju Edukacji Uczniów ze Specjalnymi Potrzebami, Kształcenie nauczycieli przygotowujące do edukacji włączającej. Profil nauczyciela edukacji włączajqcej, 2012, https://www.european-agency.org/ sites/default/files/te4i-profile-of-inclusive-teachers_Profile-of-InclusiveTeachers-PL.pdf [dostęp: 12-08-2017].

Firkowska-Mankiewicz A. Edukacja włączająca zadaniem na dziś polskiej szkoły, https://www.ore.edu.pl/wp-content/plugins/download-attach ments/includes/download.php?id=3189 [dostęp: 15-08-2017].

Konwencja Praw Dziecka, 1989 http://www.unicef.org/magic/resources/CRC _polish_language_version.pdf [dostęp: 5-07-2016].

Powszechna Deklaracja Praw Człowieka, 1948, http://www.unesco.pl/filead min/user_upload/pdf/Powszechna_Deklaracja_Praw_Czlowieka.pdf [dostęp: 07-09-2016].

Standardowe Zasady Wyrównywania Szans Osób Niepełnosprawnych, 1993, http://www.tus.org.pl/uploads/dokumenty/standardowe_zasady_wyrownywania_szans_osob_niepelnosprawnych.pdf [dostęp: 07-09-2016].

The Warnock Report, Special Educational Needs Report of the Committee od Enquiry into the Education of Handicapped Children and Young People, http://www.educationengland.org.uk/documents/warnock/warnock1978. html [dostęp: 6-06-2016]

\section{Akty prawne:}

Rozporządzenie Ministra Edukacji Narodowej z dnia 24 lipca 2015 r. w sprawie warunków organizowania kształcenia, wychowania i opieki dla dzieci i młodzieży niepełnosprawnych, niedostosowanych społecznie i zagrożonych niedostosowaniem społecznym (Dz. U. 2015, poz. 1113).

Rozporzadzenie Ministra Edukacji Narodowej z dnia 24 lipca 2015 r. w sprawie warunków organizowania kształcenia, wychowania i opieki dla dzieci i młodzieży niepełnosprawnych, niedostosowanych społecznie i zagrożonych niedostosowaniem społecznym (Dz. U. 2015, poz. 1113)

Rozporządzenie Ministra Edukacji Narodowej z dnia 30 kwietnia 2013 r. w sprawie zasad udzielania i organizacji pomocy psychologiczno-pedagogicznej w publicznych przedszkolach, szkołach i placówkach (Dz. U. 2013, poz. 532)

Rozporzqdzenie Ministra Edukacji Narodowej z dnia 28 sierpnia 2017r. zmieniające rozporządzenie $w$ sprawie zasad udzielania pomocy psychologicz- 
Agnieszka Szpak - Edukacja włączająca uczniów...

no-pedagogicznej w publicznych przedszkolach, szkołach i placówkach (Dz. U. 2017, poz. 1643)

Rozporządzenie Ministra Edukacji Narodowej z dnia 28 sierpnia 2017r. zmieniające rozporzadzenie $w$ sprawie warunków organizowania kształcenia, wychowania i opieki dla dzieci i młodzieży niepełnosprawnych, niedostosowanych społecznie i zagrożonych niedostosowaniem społecznym (Dz. U. 2017, poz. 1652)

Rozporzadzenia Ministra Edukacji Narodowej z dnia 28 sierpnia 2017 r. zmieniającego rozporzadzenie w sprawie indywidualnego obowiązkowego rocznego przygotowania przedszkolnego dzieci i indywidualnego nauczania dzieci i młodzieży (Dz. U. z 2017 r., poz. 1656)

Rozporządzenie Ministra Edukacji Narodowej z dnia 9 sierpnia 2017 r. w sprawie indywidualnego obowiq̨zkowego rocznego przygotowania przedszkolnego dzieci i indywidualnego nauczania dzieci i młodzieży (Dz. U. 2017, poz. 1616). 